\title{
Antibiotics in pig meat production: restrictions as the odd case and overuse as normality? Experiences from Sweden and Italy
}

\author{
Alexandra Waluszewski (iD ${ }^{1 凶}$, Alessandro Cinti id $^{2} \&$ Andrea Perna $^{3}$
}

For people interested in high-quality food, Italy has long been acknowledged for its production of Parma ham, salami and similar pig meat-based products. For researchers in the field of antibiotic resistance, they are known as products of a highly antibiotic-dependent production system. Italy has one of the highest consumptions of antibiotics by animals in the EU, estimated to be $244 \mathrm{mg} / \mathrm{PCU}$. By contrast, Sweden has the lowest consumption of antibiotics by animals in the EU, estimated to be $12.5 \mathrm{mg} / \mathrm{PCU}$. Thus, the Italian level is about 20 times higher than the Swedish one. The aim of this paper is to pinpoint the role of antibiotics in the Swedish and Italian production systems. What are the underlying forces and the key features of the Swedish production system-a system that can actually compensate for routine group treatment with antibiotics through precautionary health and biosecurity? What aspects are behind the different antibiotic consumption patterns in the Italian setting? We argue that the Swedish ability to compensate for routine prophylactic antibiotic group treatment was the outcome of an extensive interaction process: 'outsiders' increased the general awareness of routine antibiotic use by debating it in the media, and 'insiders' took the debate seriously and consequently acted to develop a production system that was able to compensate for routine use of antibiotics. Based on both the Swedish and Italian experiences, we argue that a legal ban on routine group treatment does not in itself guarantee a change. Those who are supposed to adopt must first share the ideas the legislation rests on; second, they must be prepared to invest in a change of material structures; third, they must foresee a 'fair' distribution of costs and benefits among producers and users-that is, an economic context in which all players are incentivised to follow the same route.

\footnotetext{
${ }^{1}$ Department of Economic History and Uppsala Antibiotic Centre, Uppsala University, Uppsala, Sweden. ${ }^{2}$ Department of Management, Università Politecnica delle Marche, Ancona, Italy. ${ }^{3}$ Department of Management, Università Politecnica delle Marche and Department of Civil and Industrial Engineering, Uppsala

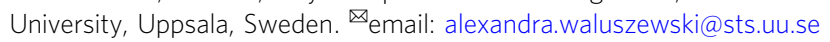




\section{Introduction}

1 hat is the relationship between Italy's famous Parma ham and the possibilities of treating secondary infections caused by diseases such as Covid-19? The question might appear far-fetched, but the high consumption of antibiotics by food animals drives antibiotic resistance (van Boeckel et al., 2017; Kirchhelle, 2018), and antibiotic resistance has a negative impact on secondary infections (Zhou et al., 2020; JPIAMR, 2020). ${ }^{1}$

Animals account for about two-thirds of the world's consumption of antibiotics. The majority of these are food animals, to which antibiotics are most often given as a precautionary measure against production-related diseases and to stimulate animal growth (Van Boeckel et al., 2015; 2017; Kirchhelle, 2018; Kahn, 2016). Antibiotic-resistant bacteria of animal origin, as Van Boeckel et al. (2015) summarise, can be transmitted to humans through the environment, food products and farmworkers:

"This widespread use of antimicrobials in livestock contributes-by means of natural selection-to the emergence of antimicrobial-resistant bacteria (ARBs) and has significant public health implications."

(Van Boeckel et al., 2015, p. 5649)

Moreover, in a highly regulated region such as Europe, "the amounts of antibiotics used to raise animals for food production is still high" (World Economic Forum Risk Report, 2013).

In this paper, we focus on the production systems in two EU countries, representing the lowest and one of the highest levels of consumption of antibiotics by production animals in this setting, and the driving forces behind the different consumption levels. More precisely, we focus on pig meat production, which conventionally, along with poultry, represents the highest consumption of antibiotics (Kirchhelle, 2018).

For people interested in high-quality food, Italy has long been acknowledged for its production of Parma ham, salami and similar pig meat-based products. For researchers engaged in antibiotic resistance ${ }^{2}$ (commonly referred to as $\mathrm{AMR}^{3}$ ), these products are known as being the outcome of a highly antibioticdependent production system. Italy is one of the EU countries with the highest consumption of antibiotics by animals, estimated to be $244 \mathrm{mg} / \mathrm{PCU}^{4}$ (ESVAC/EMA, 2020). This is about 20 times higher than the level in Sweden, the EU country with the lowest consumption of antibiotics in animals ${ }^{5}$, estimated to be $12.5 \mathrm{mg} /$ PCU (ESVAC/EMA, 2020). The European average was $103 \mathrm{mg} /$ PCU (ESVAC/EMA, 2020). ${ }^{6}$ These figures suggest that in the wake of EU regulations concerning the types of antibiotics that are allowed as feed additives, which were introduced in 1998, culminating with the 2006 EU Feed Additives Regulation banning all marketing and use of antibiotics as growth promoters in feed, other arguments for continued high consumption have emerged.

"The ban is the final step in the phasing out of antibiotics used for non-medicinal purposes. It is part of the commission's overall strategy to tackle the emergence of bacteria and other microbes resistant to antibiotics, due to their overexploitation or misuse."

\section{(European Commission, 2005, IP/05/1687)}

In 1986, about two decades before the 2006 EU ban, Sweden was the first country to legally ban growth promoter antibiotics (AGPs) and thus routine group treatments through feed and water. At the time, the Swedish consumption level was estimated to be just below $50 \mathrm{mg} / \mathrm{PCU}$. The point of departure for the Swedish engagement in systemic changes compensating for routine input of antibiotics was a consumption level in line with what Van Boeckel et al. (2017) today suggest as a maximum global goal to combat overuse of antibiotics and antimicrobials in animal-based food production:

"A global regulation putting a cap of $50 \mathrm{mg}$ of antimicrobials per PCU per year, the current global average amount, could reduce total consumption by $64 \%$."

(Van Boeckel et al., 2017, p. 1351).

Hence, the choice of Italy and Sweden as focal research settings is based on the fact that Italy is representative of 'modern' animal production practices, where antibiotic use is a core element (Van Boeckel et al., 2015; Thoms 2012), whereas the Swedish case shows that this practice is not inevitable (Kahn, 2016; Postma et al., 2015; Sjölund et al., 2015). The choice of these two settings can thus provide a deeper understanding of the forces behind the differing sales of antimicrobials for animals among EU countries (ESVAC/EMA, 2020).

"A large difference in the sales for 2018, expressed as mg/ PCU, was observed between the countries with highest and lowest sales (range 2.9 to $466.3 \mathrm{mg} / \mathrm{PCU}$ ).”

(ESVAC/EMA, 2020, p. 12)

Furthermore, there is another significant difference in antibiotic consumption in general between Italy and Sweden. Whereas Sweden and its northern neighbours mostly use older, narrow-spectrum penicillins and first-generation cephalosporins, Italy has one of Europe's highest consumptions of broadspectrum antibiotics, especially third-generation cephalosporins (Kahn, 2016). As stressed by Cassini et al., (2019), the burden of antibiotic-resistant bacteria 'varies greatly' between EU countries. Italy and Greece have a substantially higher burden of antibiotic resistance than other EU countries (Cassini et al., 2019). In Italy, more than 10,000 deaths per annum are attributed to antibioticresistant infections (Cassini et al., 2019). Although Italy has a large population of elderly people, Cassini et al. (2019, p. 64) underline that "it is notable that about a third of the deaths due to infections with antibiotic-resistant bacteria in the EU and EEA were in Italy". The lowest such death rate was reported in Iceland (in the EEA but not in the EU), followed by Estonia, the Netherlands and the Nordic countries, including Sweden. The lower consumption of antibiotics in Sweden, in general, is ascribed to an almost century-long history of control of drug use based on public health needs (Kirchhelle, 2018; Gröndal, 2018; Hobaek and Kveim Lie, 2019).

The aim of this paper is to pinpoint the role of antibiotics and the forces driving their use in the Swedish and Italian pig meatproducing settings and to discuss the requirements for a radical reduction of antibiotics to become the norm. Thus, we aim not to make a strict comparison between two types of production practices or to identify in detail the variety of practices and their direct relation to different types of resistance outbreaks, but rather to outline the systemic changes that have enabled or could enable reduced antibiotic consumption in pig meat production.

\section{Research design}

How can the use of antibiotics in the production of animal-based food be restricted when, as Chandler (2019) argues, this resource is embedded and not bounded and separable, in different arenas for economy, politics, humans and nature? What are the forces and key features behind the Swedish production system, where a number of different measures compensate for routine group 
treatment with antibiotics? What are the factors behind the different antibiotic consumption patterns in the Italian setting? These are the key questions of this paper. We also consider the difficulty caused by the distribution of the costs and benefits, where the cost of change appears mainly in the producing setting, and the benefits appear to a large extent in the healthcare setting, the environment and society at large.

The theoretical point of departure is process-oriented innovation studies, acknowledging path dependencies in terms of connectivity of social and material resources in place (Van de Ven et al., 1999; Håkansson et al., 2009; Håkansson and Waluszewski, 2002). More precisely, the study uses the conceptualisation of the Industrial Network research setting (Håkansson et al., 2009), based on the notion that economic exchange has a qualitative content, that the resources exchanged are heterogeneous-that is, dynamic - and that the value is created in directly and indirectly related resource interfaces in cross-organisational interdependencies. Hence, it is an approach that has a close kinship with notions on interdependency made in the heterodox economics research field (see e.g., Lawson, 2005; Marglin, 2008; Mirowski, 2011; Fourcade, et al., 2015).

We use the notion of the different resource interaction patterns in using, producing and developing settings (Håkansson and Waluszewski, 2007, pp. 152-156; Perna and Waluszewski, 2018, Waluszewski et al., 2018) to capture the role of antibiotics in the two focal systems. Briefly put: in the user setting, the value of a resource depends on its contribution to established systems of products and services; in the producing setting, the value depends on its contribution to investments in place in facility systems; and in the developing setting, the value depends on how it is related to knowledge production patterns in public research and private R\&D (Håkansson and Waluszewski, 2007, pp. 153-155).

The data collection is based on a combination of methods. Interviews in both the Swedish and the Italian settings were conducted with representatives of private and public actors engaged in the producing setting (farmers, slaughterhouses or food processing firms and representatives of farmers' associations), in the developing setting (veterinarians, microbiologists and medical researchers engaged in AMR) and in the user settings (representatives of the retail industry and consumer organisations). In total, 42 personal interviews including site visits were carried out, focusing on the role of antibiotics and AMR in the different empirical settings in general and for the specific respondents.

To gain data on global and country-specific animal antibiotic consumption and resistance patterns, we used reports by ESVAC, WHO and FAO. Published antibacterial studies and animal health studies were used to gain insight into the global animal antimicrobial and antibiotic resistance challenge, and social science and humanities scholars provided insight into the emergence of antibiotic-dependent animal-based food production and use settings. Furthermore, participants' observations were made during a workshop titled 'Antibiotics and Resistance-Pig Meat Production and Consumption' arranged by one of the authors at Uppsala University in May $2019,{ }^{7}$ with the ambition to gather researchers' and experts' views on Swedish producing and using systems and their emergence.

\section{Antibiotics-from a 'magic bullet' to an economic tool}

When antibiotics became a regular ingredient used in animalbased food production, the intrinsic characteristics of bacterial mutation giving rise to resistance and decreasing drug efficacy were already known (Kirchhelle, 2018; Wise, 2007, Waluszewski et al., 2018). However, up to the second half of the 1960s, concerns about resistance were overshadowed by the interest in antibiotics as feed additives to increase output and decrease costs (Thoms, 2012; Kahn, 2016; Kirchhelle, 2018). Research on antibiotics as feed additives flourished in the wake of Stockstad and Jukes groundbreaking findings on growth effects on chicken and pigs (Stockstad and Jukes, et al. 1949). As expressed by Thoms (2012, p 189):

"The literature boomed accordingly: during the 1960s, 100,000 research papers were published on the growth effects of antibiotics in animals."

The ongoing industrialisation of animal-based food production facilitated the rapid embedding of antibiotics into the food production system with a triple role as a preventive, therapeutic and economic tool (Thoms, 2012; Kahn, 2016; Begemann et al., 2018). On farms, Kirchhelle (2018) underlines, the boundaries between these applications soon blurred. Group treatment with antibiotics in feed or water became routine to speed up the growth of the animals, especially pigs and poultry, to shorten the production cycle and to increase the utilisation of space through a higher 'density' of herds. Furthermore, it facilitated a reduction in manual work and control needed for each animal (Nathan and Cars, 2014; Thoms, 2012; Kahn, 2016; Kirchhelle, 2018). In short, antibiotics became a fast track to industrialised production of animal-based food, or as Thoms (2012, p. 182) puts it:

"Antibiotics played an important-though hitherto not fully acknowledged-role in this development, as they allowed for an intensification of farming and animal husbandry that had been unthinkable before."

The perceived economic, social and political benefits of intensified animal husbandry went far beyond the setting engaged in the production of animal-based food. For the retail industry, it led to an increased supply of low-priced animal-based food products, which were used as tools to attract customer streams (Finlay, 2004; Kirchhelle, 2018). For consumers, it meant an increasing supply of low-priced animal-based food (Begemann et al., 2018; Thoms, 2012). For the pharmaceutical industry, antibiotics emerged in two parallel application areas: veterinary products and feed additives, and the latter provided an opportunity to use production residuals (Wise, 2007; Li, 2017; Kirchhelle, 2018). For the policy sphere; in both Western and Communist economies, antibiotics became a means for the rationalisation of agriculture and provision of affordable food (Kirchhelle, 2018; Begemann et al., 2018; Kahn, 2016). Thus, if antibiotics as a drug could be called a 'magic bullet ${ }^{8}$ when they were launched, they soon became an embedded economic tool, adding value to a number of resources directly or indirectly related to the use and production of animal-based food.

During the second half of the 1960s, the dark side of the extensive use of antibiotics in modernising animal-based food production received attention. Rachel Carson's Silent Spring (1962) had-at least in Western economies-triggered an awakening environmental awareness, and Ruth Harrison's Animal Machines (1964) drew attention to decreasing animal welfare and the extensive use of drugs in modern animal husbandry (Kahn, 2016; Begemann et al., 2018; Kirchhelle, 2018). When UK veterinarians delivered worrying reports of resistance outbreaks on animal farms, which also affected humans and were reported in the media, the government was forced to establish the Swann committee to address the issue (Swann et al., 1969; Kahn, 2016; Kirchhelle, 2018).

The Swann report, presented in 1969 , concluded that the use of antibiotics for growth promotion and related purposes was a threat to human and animal health because it promoted bacterial mutation and resistance (Wise, 2007; Kahn, 2016, Kirchelle, 2018, Begemann et al., 2018). However, along with the immediate need 
to alter the prevailing practice of group treatment, the short-term economic benefits were also considered, or as Kahn, (2016, p. 20) puts it:

"However, the committee recognized the important role that low concentration of antibiotics played in the growth rates of young pigs and poultry; this practise had commercial advantages."

The Swann committee proposed a solution whereby a distinction would be made between antibiotics that were acceptable for routine use in feed (such as macrolides) and those that should be reserved for human medicine (such as penicillin and tetracycline) (Swann et al., 1969; Wise, 2007; Kahn, 2016; Kirchhelle, 2018). The recommendation of the Swann committee was largely followed, both in the UK and in the European Economic Community. The use of penicillin and tetracycline as growth promotors was phased out. However, the Swann recommendation also created a back door: these drugs could still be used routinely for disease prevention in whole groups of animals with a veterinary prescription. In practice, the use of antibiotics could be dealt with as a matter of choice between antibiotics that could be accessed as feed additives and those that could be provided by veterinary prescription for precautionary use on farms (Kahn, 2016; Begemann et al., 2018; Kirchhelle, 2018).

Although the Swann committee established the connection between routine use of antibiotics for production animals and the risk of compromising the efficacy of drugs, and even though its recommendations influenced the policies of several European countries, the outcome was disappointing (Wise, 2007; Kahn, 2016; Kirchhelle, 2018; Begemann et al., 2018). European countries restricted the use of antibiotics as growth promoters, but the overall increasing dependency on antibiotics was ignored, with a few exceptions (Kirchhelle, 2018, p. 10).

With the exception of Sweden, the ongoing availability of nontherapeutic AGPs, coccidiostats, and higher-dosed prescriptions minimised early bans' impact on European agriculture until the 2000s. (Kirchhelle, 2018, p. 10)

\section{What is behind the Swedish 'exception'?}

Kirchhelle (2018) labelled Sweden 'the exception'. Why did insiders of the producing setting, with pioneering pig farmers and managers of the Swedish Farmers Association in the frontline, engage in putting an end to routine group treatment of animals with antibiotics based on normative concerns already in the early 1980 s - that is, taking on a role commonly represented by activists and interest groups? (Van de Poel, 2000; Elzen et al., 2011).

Engagement by journalists, researchers and farmers, and their cooperative organisations. When the engagement took off, Sweden was not yet part of the EU, agriculture was protected and the Swedish farmers' cooperation had majority ownership of a number of companies related to the industry: that is, feed suppliers, slaughterhouses, processing firms and equipment suppliers. Furthermore, during the second half of the 1960s, the country went through an "environmental shift" (Larsson Heidenblad, 2021, p. 12), resulting in the discussion of what modernisation of agriculture meant for humans and nature as a regular part of the public debate.

As in several other Western economies, Rachel Carson's Silent Spring had brought attention to the use of chemicals in agriculture and created an intense debate among representatives of related industries and governmental and non-governmental interests. As characterised by Flygare and Isacson (2011, p. 234):
“Rachel Carson's Silent Spring (1962) had caused a stir in Sweden, and voices were heard challenging the policy of modernization."

These voices reached the general public through increasing media coverage from concerned journalists and scientists. In Dagens Nyheter, one of Sweden's largest newspapers, journalist Barbro Soller-who was later recognised as Sweden's first environmental journalist-brought attention to the role of biocides in agriculture and the treatment of farm animals (Larsson Heidenblad, 2021). ${ }^{9}$ In a book on animal-based food production, including the role of medication of animals, she published a Swedish follow-up of Ruth Harrison's Animal Machines in 1971, with the (translated) title 'The Animal Factory $^{10}$ (Larsson Heidenblad, 2021). Prominent scientists along with engaged representatives for governmental and nongovernmental organisations, contributed to the media debate and increased public awareness (Larsson Heidenblad, 2021; Begemann et al., 2018). Political attention was manifested by the establishment of bodies such as the Swedish Environmental Protection Agency in 1967, the first of its kind, and Stockholm's hosting of the UN's first global environmental conference in 1972.

The public concerns about the increasing use of chemical use and toxic substances in agriculture and modern food production practices (Begemann et al., 2018; Vail et al., 1994) also affected the farmers themselves. They had to face not only an awakening environmental awareness but also an era of rapid rationalisation of Swedish agriculture. Up to the early 1960s, Swedish agriculture had been dominated by family-owned small farms and smallholdings spread all over the country ${ }^{11}$; these were rapidly transformed to larger units based on labour-efficient production practices (Martiin, 2015; Flygare and Isacson, 2011; Morell, 1870). The radical restructuring was debated within the agricultural setting; some farmers thought that it was too far-reaching. Although environmental demands were not promptly embraced, many farmers were concerned about the long-term consequences of the use of chemicals and the effects of toxic substances and were prepared to adapt to new requirements. For example, in the wake of the intense media debate on biocides in the mid-1960s, the engagement of individual farmers caused a decrease in the consumption of biocide-processed seed of about $50 \%$ a decade before it was legally banned in 1978 (Jordbruksverket, 2017; Larsson Heidenblad, 2021).

In the early 1980s, the use of modern production methods by farmers was reported in a series of articles in Dagens Nyheter by journalist Thomas Michelsen. Special attention was directed to the role of antibiotics in animal husbandry, where the consumption of 30 tonnes per year was mainly for production economic reasons. In 1981, Michelsen published a book on the same theme, with the translated title, 'Mass food, Swedish agriculture in the age of chemicals'. ${ }^{12}$ The series of articles and the book received a great deal of public attention-rural Sweden was still only a generation away. Many people had personal experience or had relatives with personal experience of traditional small-scale animal care and/or connections to rural life through summer cottages. People in general were, as Begemann et al. (2018) summarises, concerned about modern food production techniques and their impact on nature and animals.

Individual pig farmers and the managers at the Swedish Farmers Association were also concerned. Since the early 1950s, antibiotics had been a common ingredient in purchased feed, and several farmers worried about the long-term consequences of regular group treatment. Some pioneers started experimenting with excluding routine treatments with antibiotics, paying a higher price for antibiotic-free feed. Through personal contacts, researchers at the Swedish National Veterinary Institute 
contributed with advice. The engagement was mainly driven by environmental concerns. As one of the pioneering farmers expressed his worries:

"What happens with the soil in the long run, when manure from pigs fed with antibiotics is spread out on it?" 13

The routine group treatment of animals with antibiotics was also questioned by some concerned managers within the Swedish Farmers' Association. At this time, the Swedish Farmers Association was a resourceful cooperatively owned organisation. Flygare and Isacson (2011 p. 240) characterise its content and function:

"It had its own dairies, slaughter-houses, wholesalers, and contractors, and it backed the local farming associations in matters of marketing, information, accounting, company law, data analysis, energy, veterinary medicine, and, not least, planning for the future."

The manager's questioning of the role of antibiotics was mainly motivated by a serious worry of losing consumers' trust in animal-based food, due to the intense media debate on animal welfare and the use of chemicals and drugs. As a result, the Swedish Farmers Association presented its first antibiotic policy in 1981, recommending a voluntary phasing out of routine group treatment.

In the following years, the antibiotic issue was debated intensely within the Swedish Farmers Association by farmers as well as managers. In 1984, one of the pioneering farmers presented a bill to the Swedish Farmers' Association, suggesting that the organisation should work towards a legal ban of routine group treatment of animals with antibiotics, based on the idea that there has to be a common regulation for all farmers. The bill was accepted by the Swedish Farmers' Association and a mobilisation of political support; backed by the closely connected Centre Party, formerly the Farmers' Party, took off. The bill was passed in 1985 with support from the Social Democrats, and in January 1986 Sweden was the first country to pass a law banning the use of antibiotic growth promoters-that is, routine treatment with antibiotics in feed and water without a veterinary prescription (SFS, 1985 , p. 295). ${ }^{14}$ Thereafter, antibiotics were only allowed to be used with a veterinary prescription for the treatment of medical diseases. The Centre Party also suggested that the same ban should be applied to imported meat-a requirement that was turned down by Parliament. One of the managers at the Swedish Farmers Association summarised the mobilisation behind the ban:

"It was the farmers that asked for the ban, individually and through their organisations and related politicians."15

The law did not pass without opposition. The strongest argument against it was presented by representatives of the pharmaceutical industry, addressed directly to pioneering farmers, representatives of the Farmers' Association and the Centre Party. There were also individual farmers and veterinarians who were against the law, fearing both problems with infections and increasing production costs, while other farmers and veterinarians were concerned about negative environmental and animal welfare consequences. On the political side, the right-wing party argued that the law was not necessary since the output-that is, the food products-did not include any antibiotic residuals.

As the law was being passed in 1985, the media debate on animal husbandry was revived. The internationally recognised author Astrid Lindgren wrote about the lack of animal welfare due to modern production practices, initially through a debate article in Dagens Nyheter. ${ }^{16}$ The article prompted a veterinarian, who shared the worries and had already held discussions with
Michelsen after his debate series, to contact Lindgren. This led to a collaboration, where the veterinarian provided Lindgren with research-based data about treatment and medication of production animals, which the author transformed to articles written in the style of a fairy tale, published by a supporting editor of Expressen $^{17}$, one of Sweden's largest evening papers. The common theme of the articles was the loss of animal welfare caused by the transition from 'animal care' to 'animal production', including over-medication. The articles received a lot of attention in the media in general, and among the general public and politicians. ${ }^{18}$

In 1987, the ruling Social Democrats presented a related bill on a new animal welfare law. ${ }^{19}$ The law, which was passed in 1988 , became important because of its focus on precautionary health to reduce the consumption of antibiotics. It stipulated that sows should be free ranged and have access to straw or similar bedding material. Besides the ability to access natural behaviour, including requirements on the amount of space for each animal, precautionary health was a key issue:

"The animals shall in the future be protected not only from suffering but also from disease. Animal husbandry must therefore be focused on keeping animals healthy"20

The law received international attention and was summarised in October 1988 in the New York Times under the headline 'Swedish farm animals get a bill of rights':

'The Swedish welfare state, long renowned for its generosity and scope, is extending its reach into a new frontier: the barnyard.' ${ }^{21}$

The need for a system compensating for regular input of antibiotics. When the new animal welfare law was passed, the work to find measures to compensate for routine group treatment of animals with antibiotics had already intensified. In 1986, with the law in place, the effects of the routine treatment became clear. During the first decade after the ban-implemented without any wider preparations at the farm level-pig meat producers and veterinarians had to cope with an increased incidence of infectious diseases and higher mortality among piglets, during both the suckling and the weaning periods. This triggered a systematic development process, with disease prevention and biosecurity as key ingredients. Thus, from a beginning with pioneers such as early engaged farmers, managers at the Swedish Farmers Association, veterinarians and researchers, the mobilisation led to the involvement of representatives of the whole production system, including pig farmers, farmers' cooperative organisations, veterinarians, researchers engaged in different aspects of animal health, slaughterhouses, transporters, equipment suppliers, feed suppliers, suppliers of vaccine, etc.

All main activities from insemination to slaughter were scrutinised, and a new batch-based production system was introduced, including a new stable design based on specific sections for each stage of the breeding process. New hygiene routines were established and new types of feed were developed along with vaccines and other precautionary measures. After an initial problematic transition, the total consumption of antibiotics started to decrease, from about $50 \mathrm{mg} / \mathrm{PCU}$ before the ban of growth promoters, to around $30 \mathrm{mg} / \mathrm{PCU}$ in the early 1990s. From 1995 onwards, total consumption and group treatment continued to decrease to the current figures of about $11-12 \mathrm{mg} /$ PCU, of which about 10\% represents group treatment (SwedresSwarm, 2018).

Although no two farms are exactly alike, a production system with some specific characteristics can be outlined: 
- Sows are free to range in groups until about one week before litter. ${ }^{22}$ Then the sow is moved to her own box, where she can still move freely and pursue her building instinct. ${ }^{23}$ After littering, the sow and the piglets stay in the box for $4-6$ weeks. For the piglets, the weaning period is the most critical in terms of health, and the earlier they are weaned, the higher is the risk of infections such as diarrhoea, and the greater is the need for treatment with antibiotics. Weaning is not allowed to take place until $90 \%$ of the piglets are more than 26 days old. After the weaning period, the sow is first moved out of the box while the piglets stay for several more weeks so that they are not exposed to a new environment during this sensitive period. Then the piglets are moved to larger boxes at the same farm for the growing and fattening periods. When they are 6-7 months old and weigh about $100 \mathrm{~kg}$, they are slaughtered.

- Tail docking is not practised and tail biting is rarely observed (EU legislation forbids tail docking, but because of the generous exceptions it is still practised in many production regimes). After each movement of animals, boxes are thoroughly cleaned, and in between the boxes are mucked regularly, which is labour intensive since they are covered with straw. Before any new animal is brought into the herd, it must spend several weeks in quarantine. No visitors are allowed to enter the stable without permission, and then only with protective clothes and shoes. The transporters that move animals from stable to slaughterhouses are no longer allowed to enter the stable.

- All treatments with antibiotics or other drugs require veterinary prescriptions, and each animal must have its own medical journal. The Swedish Board of Agriculture is the owner and organiser of the 'District Veterinarians', meaning that the veterinarians are employed by the state. The District Veterinarians guarantee access to veterinarians across the whole country around the clock and are also an operational resource for the state in case of outbreaks of infectious diseases. As well as the District Veterinarians, the consultancy company 'Farm and Animal Health' (Gårds och Djurhälsan), owned by the Swedish Meat Producers' Association, Swedish Pig Farmers' Association, Swedish Beef Producers' Association and Swedish Sheep Breeders' Association, provide advice and knowledge dissemination on animal health and production economy. ${ }^{24}$

After three decades-supporting user reactions. The expectation expressed by the pioneers that the new production regime would represent a 'market advantage' was not realised. The expected positive reaction from the user side, that is the wholesale and retail industry as well as private and public consumers, disappeared. The situation escalated when Sweden became an EU member in 1995. The borders opened to an influx of pig meatbased food products produced in systems relying on significantly higher consumption of antibiotics, lower production costs, and $20-30 \%$ lower consumer prices. Swedish production fell from about 4 million pigs before entering the EU-to about 2.6 million pigs per year since. ${ }^{25} \mathrm{~A}$ dramatic restructuring of pig farms is behind these figures; essentially all small and medium-size producers closed down their activities, and the remaining larger producers increased their herd size and production volume.

It was not until around 2014; around the time of the EU election, that the wholesale and retail industry paid attention to the high consumption of antibiotics in the EU pig meat-based food production in general, and especially in Denmark, which was affected by severe outbreaks of MRSA. Media attention was once again directed the role of antibiotics in animal-based food, this time to what had actually been achieved in the Swedish producing setting. In May 2014, just before the EU election, a hypermarket belonging to the Swedish supermarket chain ICA declared that Danish pig meat would be excluded from their store. The main reason was the lack of animal welfare and because the pigs were given antibiotics as a precautionary measure, promoting antibiotic resistance. Instead, this hypermarket would only market pig meat produced in systems where antibiotics could only be used to treat sick animals with a veterinary prescription; that is, without routine group treatment.

The action from the individual ICA hypermarket created a lot of media attention and was soon followed by new policies on animal welfare and antibiotics from the three largest Swedish wholesalers: the private ICA and Axfood and the cooperative Coop. ICA declared that all suppliers, and not only suppliers of its own-brand products, had to fulfill the following requirements:

"Antibiotics may not be routinely used as a precautionary measure, but only after veterinary prescription. Antibiotics and hormones may not be used as growth promoters." 26

Similar policies were presented by $\operatorname{Coop}^{27}$, Axfood $^{28}$ and the Swedish Wholesaler Association. ${ }^{29}$ The most significant change was the branding 'Swedish meat', including consumer information about the restricted Swedish consumption of antibiotics used only as medical treatment with a veterinary prescription. Despite the consumer price for Swedish pig meat being about $0.2-0.3$ Euro higher per kilo compared with the EU average, the consumption pattern changed. As one pig meat producer expresses it:

"The growing antibiotic resistance awareness is the best thing that happened to us. At last, we are compensated for all the work we have done to get rid of antibiotics." ${ }^{30}$

\section{Italian pig meat products-a quality label overshadowing routine antibiotics in production?}

Unlike the many types of 'Silent Spring' environmental movements arising in the US and in Europe in the wake of Ruth Harrison's groundbreaking book, social and labour justice rather than ecological concern became the main issue of the social movements emerging in Italy from the late 1960s onwards (Armiero and Hall, 2010; Bertuzzi, 2019). As Armiero and Hall (2010, p. 4) characterize the roots of the different viewpoints:

"[...] ecology was middle-class science, and efforts to protect animals and plants were a diversion for members of the nobility, who were insensitive for messages being promoted by blue collar workers and radical students.'

For example, what has been characterised as Italy's late Silent Spring follow up, Laura Conti's What Is Ecology: Capital, Labor and the Environment, published in 1977 and pointing to the social relationships between humans and nature, represented a radical left environmental perspective (Barca, 2014). Although there have been some overlaps, the Italian environmental debate has largely been coloured by this labour/environment counter position (Bertuzzi, 2019); that is, engagement in environmental concerns has been filtered through shared political cultures and ideological references (Bertuzzi, 2019).

The antibiotic resistance challenge has also been somewhat absent from the Italian environmental debate. Although there are Italian voices that over time have emphasised the importance of responsible use of antibiotics for humans and animals, these views have mostly been expressed by academic researchers, and sparingly reflected in the general media. The ongoing Covid-19 
pandemic has however resulted in some media interest in the importance of protecting the efficacy of antibiotics.

The lack of media attention may explain the general public's lack of knowledge and behaviour in relation to antibiotics. Although the few studies explicitly investigating these issues point to variable awareness due to different levels of education, they also underline the general lack of awareness and understanding of how to cope with the resistance challenge (Napolitano et al., 2013; Di Gennaro et al., 2020).

In the absence of a general debate domestically, the main pressure for change comes from the EU, more recently resulting in political actions. The fact that Italy was recognised as one of the EU member states with the highest resistance level caused the European Centre for Disease Prevention and Control (ECDC) to make a 'country visit' in 2017 in order to confirm the situation in relation to human healthcare (ECDC, 2017). The ECDC report (2017, p. 6) gave a rather bleak view of the (lack) of recognition of the AMR challenge (2017, p. 6):

"During conversations in Italy, ECDC often gained the impression that these high levels of AMR appear to be accepted by stakeholders throughout the healthcare system, as if they were an unavoidable state of affairs."

The reports from the EU and ECDC denouncing the challenging Italian antibiotic resistance situation eventually forced action in the political sphere. The pressure was further fueled by the economic burden of AMR on the health system, something that also pointed to the overuse of antibiotics in the animal-based food production system. In 2017 a 'National Plan to Fight Antimicrobial Resistance' (PNCAR 2017-2020) was issued, including targets for the reduction of the use of antibiotics and control of healthcare-associated infections (Cassini et al., 2019). In 2018, this National Plan was followed by a specific measure aimed at reducing the use of antibiotics in animals: a mandatory requirement for electronic veterinary prescriptions. Furthermore, on February 11, 2020, four parliamentary motions ${ }^{31}$, brought to court by the Social Affairs and Health Committee, were approved unanimously. These guideline-like measures aimed to increase investments in public research, public health and food control and monitoring the use of antibiotics in animal-based food production. Still, none of these regulations included imperative legislation blocking the use of antibiotics as 'prophylaxis therapy'. Instead, the overall message of PNCAR 2017-2020 was to communicate and disseminate 'best practices' in the use of antibiotics. However, it allows an 'antibiotic-free' label to be used on meats if the animals have not been given antibiotics in the last 4 weeks before slaughter. $^{32}$

The Italian PNCAR plan was followed by significant media attention on the relation between modern animal-based food production, use of antibiotics and antibiotic resistance. In the spring of 2019, the RAI television company's investigative journalism series 'Presadiretta' devoted a programme to the Italian pig meat production system and the high level of routine group treatment of animals with antibiotics, and how this is related to AMR. The programme included a report from a Swedish pig farm and discussions with Swedish researchers, focusing on the measures behind Sweden's restricted antibiotic consumption in food animals ${ }^{33}$. 'Presadiretta', however, was not followed by any general media attention to the topic of animal-based food production and antibiotic resistance. Comments made in social media were also more or less exclusively oriented to the question of the consumer's risk of being exposed to residuals of antibiotics in animal-based food. Hence, public reactions caused by the program can be regarded as an illustration of the lack of general understanding of the phenomenon of antibiotic resistance and furthermore, of the wide gap between the academic research settings engaged in different aspects of antibiotic resistance and the interests of the media world.

Although 'Presadiretta' directed specific criticisms towards the production methods of the large pig meat producers in northern Italy, accusing them of a severe overuse of antibiotics, the producers' reaction can be characterised as 'wait and see'. These producers, who dominate the industry from a volume perspective, seem to fear addressing the problem of non-therapeutic use of antibiotics for animals, because of predicted short-term effects, such as the loss of the famous reputation of Italian food for high quality, a fear that seems to be shared by policymakers. Instead, so far it has been the small producers located in central Italy that have adapted in terms of an increasing transition to 'organic' production methods, including abandoning routine use of antibiotics. In this region, it was the chicken producers that most reacted most rapidly, followed, in small steps, by 'organic' pig meat producers.

A producing setting focused on the 'Italian food' brand-not on the production practices. Since the 1950s, 'precautionary' routine group treatment with antibiotics has been a common denominator of the Italian pig meat-producing setting. Although there is a wide variation in the size and modernity of farms, from a volume perspective, production is dominated by large integrated companies in the North, covering activities from breeding to the branding of end products ${ }^{34}$.

Routine group treatment of pigs with antibiotics became part of everyday Italian production routines in the 1950s, initially as a response to the needs of the new breeds imported from England. The English imported breed Large White was more prolific and fertile than traditional Italian breeds and was easier to adapt to life in tight spaces, but also tended to get sick more easily and required regular antibiotic treatment ${ }^{35}$.

Contemporary Italian pig meat production covers about $60 \%$ of domestic consumption, and about $40 \%$ is imported, mainly from Germany, the Netherlands, Spain and France. Between 2010 and 2020, there has been decreasing in the number of livestock, and in particular in the number of sows $(-18 \%)$. At the same time, there has been an increase in imports of pig meat $(+29 \%)$ and of piglets $(+26 \% \text { of piglets imported })^{36}$. The high consumption of antibiotics is accompanied by a high level of antibioticresistant bacteria in pig livestock. For example, about $35 \%$ of the Italian pig livestock are infected by LA MRSA ${ }^{37}$, whereas the Swedish Public Health Agency ${ }^{38}$ reports only a few cases of this antibiotic-resistant bacterium among Swedish production pigs.

An antibiotic-based production system with scale variations. The production methods applied by the dominant large pig meat producers are characterised by a high degree of specialisation. Most Italian pig farms practise 'open cycle' farming, where-from birth, until they are ready to be slaughtered (at $160 \mathrm{~kg}$ ) - pigs are bred in a system in which they are transported between different farms, specialised in different stages of the production cycle; that is, depending on the age of the piglets. Thus, a basic characteristic of the Italian producing setting is the intense trading and transporting of live animals.

The production of piglets, in general, takes place on specialised farms. It is common practice to put the sow in a narrow cage before and after farrowing, for 123 days per year on average $e^{39}$. The piglets remain with the sow until the end of the weaning phase; that is until they reach a weight of about $30-40 \mathrm{~kg}$. This means that the piglets can be moved away from the sow after about 3 weeks, transported, and mixed with other piglets at another type of farm, specialising in the subsequent phase of 
skinning and fattening. Moving piglets at such an early stage have at least two consequences for their health.

First, when the weaned piglets are mixed with others they have not been in contact with at the farm where they are born, they react with stress and aggressive behaviours. They get scratches on their bodies, increasing the risk of infection. They bite the tails of other pigs, which is the reason for systematic tail docking, and often also sanding of the teeth. This is a painful experience that increases stress and weakens the immune system of the animals.

Second, the transporting and mixing of piglets from different farms increases the spread of infections. Although some farms have adopted the all-in all-out system, and practise total disinfection of the stable whenever a batch of pigs is moved, the transportation and mixing increase the risk of infection. To reduce the risks of disease, antibiotic prophylaxis-that is, regular group treatment-is often applied.

Despite European legislation, it is common for pigs and piglets do not to have access to straw or similar material. The same legislation also stipulates that animals should have a place to lie down and a separate place to defecate. However, it is common that boxes have no such separate places. The health conditions of the pigs are further affected by the high levels of humidity (up to $80 \%)$ and temperature $\left(30-35{ }^{\circ} \mathrm{C}\right)$, reached during hot seasons. These levels are far higher than those indicated by the ministry's guidelines, increasing pigs' levels of aggression and weakening their immune system, affecting the animals' adipose organs.

Although all treatments with antibiotics or other drugs have to be made with veterinary electronic prescriptions and each animal has to be tracked into a medical journal, routine group treatments are accepted as a prophylactic health measure. Although Italian veterinarians are not paid for prescriptions of antibiotics-a practice that still is applied in other European countries-there are other conflicts of interest involved. One is caused by the three different types of professional typologies of veterinarians. 'Firm veterinarians' are directly employed by large meat producers. Private veterinarians are used by smaller animal breeders. Public veterinarians are employed by the state and have the role of controlling and monitoring firm's veterinarians. However, the public veterinarians can also operate as private veterinarians, potentially leading to a conflict of interest. Thus, there is a lack of distinct 'firewalls' between the interests of commercial (pig) meat producers and the public interests of control of animal health, including antibiotic resistance.

The large pig meat producers ( $>500$ sows) are obliged to carry out self-monitoring in relation to purchasing antibiotics. The data is monitored by local health offices, so in case of anomalies, targeted inspections are carried out and reported to the Ministry of Health.

However, publicly organised inspections at production sites and the consequences of disregarding animal health regulations are restricted. Prophylactic use of antibiotics is widely accepted as part of the production routine.

Restricted user reactions. Over recent years, wholesale and retail settings have started to pay attention to the way antibiotics are used in animal-based food production. In the spring of 2017, Coop-Italia became the first retailer to declare support for animal welfare in food production, including the reduction of antibiotics. The campaign included demands for a progressive reduction of antibiotics on farms in order to combat resistance. Coop-Italia's initiative created a ripple effect and several other wholesale and retail companies adopted similar policies.

However, a common denominator of those initiatives was their 'marketing experiment-like' character, resting on the understanding that the general public's awareness of antibiotic resistance is poor and widely underestimated ${ }^{40}$. This means that so far, wholesalers and retailers have not imposed any mandatory requirements on the pig meat food producers. Furthermore, the consumer reactions to the small number of producers that are using the 'antibiotic-free' label seems to be a combination of scepticism and resignation, as if this type of communication was just another marketing operation to increase the price of the product. Table 1-3 summarises the basic characteristics of the Swedish and Italian pig meat production systems.

\section{Conclusion}

If combatting antibiotic resistance through the development of new drugs, new diagnostics and new vaccines are measures dependent on future research advances and heavy investments in their industrialisation, a radically reduced consumption of antibiotics in animal-based food is a well-tried existing solution,

Table 1 Swedish and Italian consumption of antibiotics for animals and production figures related to pig meat-based food (2017).

\begin{tabular}{|c|c|c|}
\hline & Sweden & Italy \\
\hline Antibiotic consumption mg/PCU & $12.5 \mathrm{mg} / \mathrm{PCU}$ (2018, ESVAC/EMA, 2020) & 244 mg/PCU (2018, ESVAC/EMA, 2020) \\
\hline Pig production, slaughtered pigs & 2.5 million/year & 11.4 million/year \\
\hline Pig production share, EU & $1 \%$ & $6 \%$ \\
\hline Pig breeds & Landrace-Yorkshire, Hampshire Duroc & Large White, $70 \%$ heavy pigs for protected products ${ }^{a}$ \\
\hline Pig production farms & 1.272 & $\begin{array}{l}26.582 \text { (great size variation; } 5 \% \text { of farms represents } \\
59 \% \text { of production) }\end{array}$ \\
\hline Geographic concentration & $\begin{array}{l}\text { South, mid and west of Sweden. }<5 \% \text { of pig population in } \\
\text { north of Sweden. }\end{array}$ & $\begin{array}{l}\text { Northern Italy, } 27 \% \text { of pig production farms, } 87 \% \text { of } \\
\text { pig population }\end{array}$ \\
\hline Sows & 120.000 & 561.640 \\
\hline Sows/farm & 173 & $\begin{array}{l}53 \text { (great size variation, } 60 \% \text { of farms less than } \\
10 \text { pigs.) }\end{array}$ \\
\hline Slaughter pigs/farm & 823 & 407 \\
\hline Slaughtered pigs & 116.000 tons & 1.484 .515 tons \\
\hline Pigs/sow/year & 26.7 & 18.4 \\
\hline Pigs/sow/litter & 14.3 & 13.9 \\
\hline Slaughtered pigs/sow/year & 26 & 26.43 \\
\hline \multirow[t]{2}{*}{ Import of pig meat } & Import 27\% & Import 37,3\% \\
\hline & 116.000 tons & 1.059 .840 tons \\
\hline Export of pig meat-based food & - & 413.440 tons \\
\hline
\end{tabular}

aprotected Designation of Origin, only heavy pigs for protected products such as air-dried ham, salami, and other dried and smoked products (not allowed; New Hampshire, Piétrain, Spotted Poland). 
Table 2 Basic antibiotic requirements and resistance levels.

\begin{tabular}{lll} 
& Sweden & Italy \\
\hline AGP & Forbidden since 1986 & Forbidden (EU reg.) since 2006 \\
Individual treatment & $90 \%$ & $10 \%$ \\
Main antibiotic classes sold & Penicillin & Tetracycline (32\%), Penicillin (24\%), \\
LA-MRSA in slaughter pig herds & LA-MRSA free & $34.9 \%$ \\
ESBL in slaughter pig herds & Occasionally, a few cases reported & $17.6 \%$ \\
Salmonella & Salmonella Free & $9.64 \%$ source EFSA (sample 716 units tested) \\
& & $5.3 \%$ source OFFICIAL NATIONAL CONTROLS (sample 5.641 pig \\
& & carcasses) \\
& $1.6 \%$ SELF-MONITORING (sample 14.368 pig carcasses)
\end{tabular}

'The latest screening of pigs in Sweden was in a nucleus and multiplying pig herds in 2014. MRSA was not detected, indicating a favourable situation.' (Swedres-Swarm, 2018, p. 96).

'The European Union summary report on trends and sources of zoonoses, zoonotic agents and food-borne outbreaks in 2017' (EFSA and ECDC, 2018). This data has been elaborated from the tables in the appendix, related to that report. However, it has emerged that the related sample is very small, just 716 units tested.

\section{Table 3 Basic production characteristics and requirements.}

\begin{tabular}{|c|c|c|}
\hline Characteristics/requirements & Sweden & Italy \\
\hline \multirow[t]{5}{*}{ 'All in, all out' / batch prod } & Batch production, breeding and fattening (close & High heterogeneity: \\
\hline & cycle) most common. & Two types of systems: \\
\hline & & 1) Most common: Open system. Breeding and fattening at \\
\hline & & specialised farms. Often batch wise. \\
\hline & & $\begin{array}{l}\text { 2) Breeding and fattening (close cycle), less adapted to batch } \\
\text { production. }\end{array}$ \\
\hline Space, $\mathrm{m} 2 /$ sow with piglets & $6 \mathrm{~m} 2$ & $4.6 \mathrm{~m} 2$ \\
\hline \multirow[t]{2}{*}{ Lactation period } & 28 days & 21 days in opens systems. \\
\hline & & 28 days in closed systems. \\
\hline Tail docking & Forbidden & $\begin{array}{l}\text { Common practice (up to } 90 \% \text { ) Allowed if there are substantiated } \\
\text { and proven needs. }\end{array}$ \\
\hline \multirow[t]{2}{*}{ Fixation of sow } & Forbidden & About 123 days/year, common practice. \\
\hline & & EU allows sow fixation $150-170$ days/year. \\
\hline Slatted floor & Forbidden & Allowed, with specific features for materials and width of slots. \\
\hline \multirow[t]{2}{*}{ Bedding material, e.g., straw } & Required & Required a place suitable to rest, dry and cleaned. \\
\hline & & Required bedding material only for piglets. \\
\hline
\end{tabular}

practised and researched over several decades, at least in a few modern production regimes.

This is not to say that the search for new drugs represents 'rocket science', and reducing consumption represents simple 'implementation'. Rather, as this paper has illustrated, a production system able to compensate for antibiotic routine group treatment requires a systematic change in a number of material and social resources related to animal-based food production in the producing setting and in related developing settings.

In order to achieve such systemic changes based on normative concerns, previous studies have outlined the importance of outsiders' voices, such as those of different interest groups (Van de Poel, 2000; Elzen et al., 2011). However, for ideas brought forward by outsiders to not only be accepted by insiders but also motivate them to invest in change-that is, in the development of investments in place (Håkansson and Waluszewski, 2002)-they must have expectations of at least some possibility of a positive return on investments (Håkansson and Waluszewski, 2002; 2007).

In the Swedish setting, both of these requirements were fulfilled, at least on paper. The outsiders' decade-long environmental concerns were regularly debated in media, including concerns about animal-based food production and the role of chemicals and antibiotics. This made an impression on those exposed directly to these issues through their businesses, organisations and professional work. Insiders' engagement in a change of existing production practices rested on the trust that the costs, which mainly appeared in the pig meat-producing setting, would be shared with others. This is partly through compensation from the political sphere, which was never realised, and partly through support from the retail industry, which took three decades to realise.

As well as individual pioneering farmers, the insiders included the Swedish Farmers Association, which at that time represented ownership control of a significant number of organisations and businesses related to pig meat production, such as suppliers of feed, equipment and slaughter. The Farmers Association also had extensive relationships with the political sphere. Last but not least, researching and practising veterinarians joined forces to engage in what was later called the Swedish Model of treatment of production animals. This was thus a resourceful network, which furthermore-as long as Sweden was outside the EU-was protected from an influx of products from antibiotic-based production regimes.

The mobilisation of almost an entire producing setting proved to be sufficient to achieve a production practice able to compensate for routine group treatment of animals with antibiotics. However, entry to the EU revealed the full consequences of being a minor producing setting from a global perspective, with a rather unique production practice, when neither the retail industry nor consumers distinguished the output from products stemming from antibiotic-based production regimes. Almost half of the 
production volume was lost-and has still not recovered-and small and medium-sized producers went out of business. Swedish pig meat farmers had to pay a high cost for a change to benefit the healthcare setting and society at large.

It took 30 years and a new wave of media criticism from outsiders, this time directly focused on the retail industry's promotion of imported products from antibiotic-based production regimes, before it acted and started to promote the Swedish production practice. Eventually, consumers responded and accepted a somewhat higher consumer price.

The economic burden carried by the Swedish pig meat farmers illustrates the Italian ambivalence towards change. As Kirchhelle (2018) asks, why should farmers accept being put at a disadvantage, which will be the case if not all are following the same rules. This points to the importance of outsiders who are not only prepared to campaign for change but also to share the costs. Italy's worldwide high-quality food brand has paradoxically hindered both outsiders' attention to its production practices and insiders' preparedness to draw attention to its high reliance on regular antibiotic group treatments. Although there are engaged researchers, activists and organic food producers who, along with the EU bodies, are calling for change, the contemporary production practice, domestic policy bodies and industry representatives are keen to uphold the 'Italian food' brand. Drawing attention to the dark sides of their production practices is considered to come with a high risk of denigrating the brand.

Thus, the persistence of antibiotic-based production systems is not due to lack of scientific knowledge and practical experiences, or unsatisfactory outcomes of systems able to compensate for antibiotics through precautionary health and biosecurity, but rather to a lack of ability to disseminate knowledge to the general public and to find a distribution of costs and benefits that can motivate investments to change production practices.

When the new EU regulations on veterinary medicines and medicated feed come into force on January 28, 2022, all forms of routine use of antibiotics in animal-based food production will be prohibited, including preventative group treatments. ${ }^{41}$ If the new regulation will contribute to the long-awaited change within EU; Italy included, is still an open question. Another is what reactions Italy and other export-oriented producers will meet in global trade if they adapt to the new regulations. (The question of how to cope with requirements of reduced antibiotic consumption when engaged in global trade is probably also raised by British producers after leaving EU).

However, the experience from the Italian and Swedish settings stresses the importance of significantly more extensive measures than regulation. Above all, it points to the need for serious and enduring interaction among actors who, despite their different roles, different economic strengths and often clashing interests, are prepared to act on knowledge about antibiotic resistance and to make the investments necessary to combat it in the producing setting - and to pay for it in the user setting. This remains a considerable economic, political and social challenge.

\section{Data availability}

In order to avoid the risk of compromising individual privacy, the original data generated through personal interviews in the Swedish and Italian settings are not publicly available. Information about this data can be provided by the corresponding author.

Received: 15 July 2020; Accepted: 28 June 2021;

Published online: 14 July 2021

\section{Notes}

1 https://www.jpiamr.eu/considerations-for-antibiotic-resistance-in-the-covid-19pandemic/.

2 Antibiotic resistance is a natural phenomenon that occurs when bacteria develop the ability to survive in the presence of one or more antimicrobials, such as antibiotics. However, it is accelerated by overuse and misuse of antibiotics, making standard treatments ineffective, causing infections to persist and spread (see e.g., https://www. reactgroup.org/).

3 'Antimicrobials', 'antibacterials' and 'antibiotics' are commonly used interchangeably, despite there being important differences between these words. Antimicrobials is a wider term that includes all agents that act against microorganisms, namely bacteria, fungi, viruses and protozoa. Antibacterials act only on bacteria. Broadly defined, this term encompasses all compounds that act against bacteria, including antibiotics. Antibiotics are produced naturally by microorganisms and kill or inhibit the growth of other microorganisms, mainly bacteria. (https://www.reactgroup.org/toolbox/ understand/antibiotics/). This paper concentrates on antibiotic resistance.

4 Population Correction Unit, amount of antibiotics for every $\mathrm{kg}$ of bodyweight at time of treatment.

5 Two European countries outside the EU have lower figures: Norway and Iceland.

6 Consumption was higher in southern Europe, where Spain and Cyprus also reached $>200 \mathrm{mg} /$ PCU. (ESVAC/EMA 2019).

7 Seven invited keynote speakers presented different views on the innovations in the Swedish system. Participants' views ranged from the perspective of farmers' cooperation organisations, to research experiences in veterinary medicine, agricultural studies, business studies, economic history and health studies. Along with key discussants, there were 40 participants mainly representing academic research on this topic. The workshop was arranged by one of the authors and participating observations were made by two of the authors (https://www.sdu.dk/-/media/files/ workshop+invitation.pdf).

8 Inspired by Nobel laureate Paul Erlich's concept for any drug that can kill a microbe without harming the body itself.

9 In1971 Barbro Soller was engaged by Swedish Television to develop its environmental news journalism.

10 Djurfabriken.

11 Only about $10 \%$ of farmland belonged to large estates, mainly located in the south of Sweden (Morell, 2011)

12 Massmaten, svenskt jordbruk $i$ kemiåldern.

13 Interview of a farmer in mid-Sweden, 2019-04-25.

14 https://www.riksdagen.se/sv/dokument-lagar/dokument/svensk-forfattningssamling/ lag-1985295-om-foder_sfs-1985-295, 2019-05-17.

15 Interview, 2018-11-20.

16 Dagens Nyheter, Debatt, 1985-05-03.

17 Dagens Nyheter, 1985-05-05; Expressen, 1985-22-09, 1985-10-27, 1986-01-03; 1987 01-14.

18 Later on, Astrid Lindgren and Kristina Forslund published a book based on the debate (Min ko vill ha roligt, Rabén \& Sjögren, 1990).

19 Proposition 1987/88:93. https://www.riksdagen.se/sv/dokument-lagar/dokument/ proposition/om-djurskyddslag-mm-_GB0393/html.

20 https://www.riksdagen.se/sv/dokument-lagar/dokument/proposition/omdjurskyddslag-mm-_GB0393/html. Author's translation.

21 New York Times, 1988.10.25.

22 The productive life of a sow begins at around 1 year of age and includes a continuous cycle of insemination, gestation and farrowing after 114 days and suckling for an average of 28 days.

23 All boxes must include a complete floor and all pigs must have access to bedding material such as straw. For pigs of all ages, $65-75 \%$ of the box floor should be complete, covered the bedding material and free from manure drain. The boxes must have a separate manure corner. On average, the sow with piglets has about $50 \%$ more space than EU legislation requires, the fattening pigs have about $30 \% \mathrm{more}$, and slaughter pigs have about $40 \%$ more. Furthermore, the boxes must have daylight and a certain level of air quality.

24 https://distriktsveterinarerna.se/vart-uppdrag/om-distriktsveterinarerna; https:// www.gardochdjurhalsan.se/radgivning-tjanster/gris/; http://www.sds-web.se/en/.

25 https://jordbruksverket.se/download/18.28f4d91b172cdd65219b3acb/ 1592760271492/201801.pdf.

26 https://www.ica.se/XformFiles/ICA-djuromsorg-2017.pdf 2019-05-16.

27 https://www.coop.se/vart-ansvar/hallbarhetsarbete/kott/djurvalfard/, 2019-05-16.

28 https://www.axfood.se/kontakt/fragor-och-svar/antibiotika/, 2019-05-16.

29 https://www.svenskdagligvaruhandel.se/dagligvaruhandeln-tar-stallning-minskadantibiotikaanvandning/, 2019-05-16.

30 Interview, Swedish farmer, October 2018.

31 In February 2020, four parliamentary motions were approved unanimously, brought to the court by the Social Affairs and Health Committee: Mandelli, Pedrazzini et al., n. 1-00022, Molinari et al., n. 1-00327, Lollobrigida et al., n. 1-00328, Carnevali, Nappi, Rostan, De Filippo et al., n. 1-00329. 
32 https://www.gazzettaufficiale.it/atto/serie_generale/caricaDettaglioAtto/ originario?atto.dataPubblicazioneGazzetta $=1991-06-29 \&$ atto. codiceRedazionale $=091 \mathrm{~A} 2848$ \&elenco30giorni $=$ false-2020-04-20.

33 https://www.youtube.com/watch?v=9j_w0L2A4A-2019-07-10.

$34 \mathrm{http}: / /$ dati.istat.it/Index.aspx?DataSetCode=DCSP_CONSISTENZE, 2020-04-15.

35 Large White is dominant. Other breeds are (from the most common): Landrace, Duroc, Pietrain, Hampshire, Cinta Senese, Romagnola or Mora, and Nero from Calabria.

$36 \mathrm{http}: / /$ dati.istat.it/Index.aspx?DataSetCode=DCSP_CONSISTENZE, 2020-04-15.

37 Livestock-associated methicillin-resistant Staphylococcus aureus.

38 https://www.folkhalsomyndigheten.se/nyheter-och-press/nyhetsarkiv/2015/januari/ ingen-mrsa-bland- avelsgrisar-i-sverige/ -2020-6-19.

39 The productive life of a sow begins around 10 months of age, when it is introduced to the continuous cycle of insemination, gestation, farrowing and suckling, and ends at around 3 years of age.

40 For instance, from the human use of antibiotic perspective, an investigation conducted by the infectious diseases department of the ISS (National Health Institute) on the controls and the degree of monitoring of Italians with respect to all the use of antibiotic drugs has revealed that only the $50 \%$ of Italians know what antibiotics are and what they are used for, $40 \%$ would take these drugs without a prescription and $43 \%$ ignore the phenomenon of antibiotic resistance. https://www. epicentro.iss.it/antibiotico-resistenza/giornataAntibioticiItalia - 2020-3-11.

41 https://eur-lex.europa.eu/eli/reg/2019/6/oj; https://eur-lex.europa.eu/legalcontent/ EN/TXT/?uri=CELEX:32019R0004

\section{References}

Armiero M, Hall M (2010) Il Bel Paese. In:Armiero M, Hall M(eds) Nature and History in Modern Italy. Ohio University Press, Athens, Ohio, pp. 1-15

Barca S (2014) Laboring the earth: transnational reflections on the environmental history of work. Environ Hist 19:3-27

Bertuzzi N (2019) Political generations and the Italian environmental movement (s): innovative youth activism and the permanence of collective actors. Am Behav Sci 63(11):1556-1577

Begemann S, Perkins E, Van Hoyweghen I, Christley R, Watkins F (2018) How political cultures produce different antibiotic policies in agriculture: a historical comparative case study between the United Kingdom and Sweden. Sociol Ruralis 58(4):765-785

Carson R (1962) Silent Spring. Houghton Mifflin, Boston

Cassini A, Diaz Högberg L, Plachouras D, Quattrocchi A, Hoxha A, Skov Simonsen G, Colomb-Cotinat M, Kretzschmar ME, Devleesschauwer B, Cecchini M, Ait Ouakrim D, Cravo Oliveira T, Struelens MJ, Suetens S, Monnet DL, the Burden of AMR Collaborative Group (2019) Attributable deaths and disability-adjusted life-years caused by infections with antibiotic-resistant bacteria in the EU and the European Economic Area in 2015: a populationlevel modelling analysis. Lancet Infect Dis. 19:56-66

Chandler, C.I.R (2019) Current accounts of antimicrobial resistance: stabilisation, individualisation and antibiotics as infrastructure. Pal Commun 5(1): https:// doi.org/10.1057/s41599-019-0263-4

Conti L (1977) Che cos'è l'ecologia. Capitale, lavoro, ambiente. Mazzotta, Milano

Di Gennaro F, Marotta C, Amicone M, Bavaro DD, Bernaudo F, Frisicale EM, Kurotschka PK, Mazzari A, Veronese N, Murri R, Fantoni M (2020) Italian young doctors' knowledge, attitudes and practices on antibiotic use and resistance: a national cross-sectional survey. J Global Antimicrob Resist 23:167-173

ECDC (2017) European Centre for Disease Prevention and Control. ECDC country visit to Italy to discuss antimicrobial resistance issues. ECDC, Stockholm

Elzen B, Geels FW, Leeuwis C, Mierlo B (2011) Normative contestation in transitions 'in the making': Animal welfare concerns and system innovation in pig husbandry. Res Policy 40(2):263-275

ESVAC/EMA (2020) European Medicines Agency, European Surveillance of Veterinary Antimicrobial Consumption. Sales of veterinary antimicrobial agents in 31 European countries in 2017. Trends from 2010 to 2018. Tenth ESVAC report. European Medicines Agency, Brussels

European Commission 2005. Ban on antibiotics as growth promoters in animal feed enters into effect. Press release, 22 December. https://ec.europa.eu/ commission/presscorner/detail/en/IP_05_1687

European Food Safety Authority and European Centre for Disease Prevention and Control (EFSA and ECDC) (2018) The European Union summary report on trends and sources of zoonoses, zoonotic agents and food-borne outbreaks in 2017. https://efsa.onlinelibrary.wiley.com/doi/10.2903/j.efsa.2018.5500

Finlay MR (2004) Hogs, Antibiotics, and the Industrial Environments of Postwar Agriculture. In:Schrepfer SR, Scranton P (eds) Industrializing Organisms: Introducing Evolutionary History. Routledge, New York

Flygare IA, Isacson M (2011) The tension between modernity and reality, 19452010. In: Myrdal J, Morell M (eds) The Agrarian History of Sweden. From 4000 BC to AD 2000. Nordic Academic Press, Lund, pp. 214-256
Fourcade M, Ollion E, Algan Y (2015) The superiority of economists. J Econ Perspect 29(1):89-114

Gröndal H (2018) Unpacking Rational Use of Antibiotics: Policy in Medical Practice and the Medical Debate. Digital Comprehensive Summaries of Uppsala Dissertations from the Faculty of Social Sciences. Acta Universitatis Upsaliensis, Uppsala

Håkansson H, Ford D, Gadde L-G, Snehota I, Waluszewski A (2009) Business in Networks. Wiley, Chichester

Håkansson H, Waluszewski A (2002) Managing technological development. IKEA the environment and technology. Routledge, London, New York, NY

Håkansson H, Waluszewski A (2007) 'Interaction: the only means to create use'. In: Håkansson H, Waluszewski A (eds) 'Knowledge and Innovation in Business and Industry. The importance of using others. Routledge, London, pp 147-167

Håkansson H, Ford D, Gadde L-E, Snehota I, Waluszewski A (2009) 'Business in. Networks'. Wiley \& Sons, Chichester

Harrison R (1964) Animal machines. The new factory farming industry. Ballantine Books, New York

Hobaek B, Kveim Lie A (2019) Less is more: Norwegian drug regulation, antibiotic policy, and the "need clause". Milbank Q 97(3):762-795

JPIAMR, Considerations, https://www.jpiamr.eu/considerations-for-antibiotic resistance-in-the-covid-19-pandemic/

Jordbruksverket (2017) Utsäde-skadegörare, analys och behandling. Jordbruksverket, Jönköping

Kahn LH (2016) ONE HEALTH and the politics of antimicrobial resistance. John Hopkins University Press, Baltimore

Kirchhelle C (2018) Pharming animals: a global history of antibiotics in food production (1935-2017). Pal Commun 4:96

Larsson Heidenblad D (2021) Den gröna vändningen: En ny kunskapshistoria om miljöfrågornas genombrott under efterkrigstiden. Kriterium, Göteborg

Lawson T (2005) The nature of heterodox economics. Cambridge J Econ 30 (4):483-505

Lhermie G, Gröhn YT, Raboisson D (2017) Addressing antimicrobial resistance: an overview of priority actions to prevent suboptimal antimicrobial use in foodanimal production. Front Microbiol 7:2114

Li J (2017) Current status and prospects for in-feed antibiotics in the different stages of pork production-A review. AJAS 30(12):1667-1673

Marglin SA (2008) The dismal science: how thinking like an economist undermines community. Harvard University, Cambridge

Martiin C (2015) Modernized Farming but Stagnated Production: Swedish Farming in the 1950s Emerging Welfare State. Agric Hist Soc 89(4):559-583

Mirowski P (2011) Science-Mart. Privatizing American Science. Harvard University Press, Cambridge, Mass

Michelsen T (1981) Massmaten: svenskt jordbruk i kemiåldern. Rabén \& Sjögren, Stockholm

Morell M (1870) Agriculture in industrial society. In: Myrdal Janken, Morell Mats (eds) The Agrarian History of Sweden. From 4000 BC to AD 2000. Nordic Academic Press, Lund, pp. 165-213. 1945

Napolitano F, Izzo MT, Di Giuseppe G, Angelillo IF (2013) Public knowledge, attitudes, and experience regarding the use of antibiotics in Italy. PLoS ONE 8 (12):e84177

Nathan C, Cars O (2014) Antibiotic resistance-problems, progress, and prospects. New Engl J Med 371:1761-1763

Perna A, Waluszewski A (2018) The Interplay Between Innovation and Accounting: The Border-Crossing Q-Linea Project and Its Within-Border Accounting. In:Carlsson-Wall M, Håkansson H, Kraus K, Lind J, Strömsten T (eds) Accounting, Innovation and Inter-Organisational Relationships. Routledge, New York, pp. 12-28

Postma M, Stärk K, Sjölund M, Backhans A, GrosseBeilage E, Lösken S, Belloc C, Collineau, Iten D, Visschers V, Nielsen EO, Dewulf J (2015) Alternatives to the use of antimicrobial agents in pig production: a multi-country expert ranking of perceived effectiveness, feasibility and return on investment. Prevent Veterin Med 118:457-466

Sjölund M, Backhans A, Greko K, Emanuelsson U, Lindberg A (2015) Antimicrobial usage in 60 Swedish farrow-to-finish pig herds. Prevent Veterin Med 121:257-64

Soller B, 1971 Djurfabriken. Stockholm: Rabén och Sjögren, Stockholm

Stokstad EL, Jukes TH et al. (1949) The multiple nature of the animal protein factor. J Biol Chem 180:647-654

Swann MM et al. (1969) Report of the Joint Committee on the Use of Antibiotics in Animal Husbandry and Veterinary Medicine. Her Majesty's Stationery Office, London

SFS (1985) Lag om foder. Svensk författningssamling, Stockholm, 295

Swedres-Swarm (2018) A report on Swedish Antibiotic Utilisation and Resistance in Human Medicine (Swedres) and Swedish Veterinary Antibiotic Resistance Monitoring (Svarm). Public Health Agency of Sweden and National Veterinary Institute, Stockholm 
Thoms U (2012) Between promise and threat. NTM J Hist Sci Technol Med 20:181-214

Vail DJ, Hasund KP, Drake L (1994) The greening of agricultural policy in industrial societies: Swedish reforms in comparative perspective. Ithaca, NY: Cornell University Press

Van Boeckel TP, Brower C, Gilbert M, Grenfell BT, Levin SA, Robinson TP, Teillant A, Laxminarayan R (2015) Global trends in antimicrobial use in food animals. Proc Natl Acad Sci USA 112(18):5649-5654

Van Boeckel TP, Glennon EE, Chen D, Gilbert M, Robinson TP, Grenfell BT, Levin SA, Bonhoeffer S, Laxminarayan R (2017) Reducing antimicrobial use in food animals. Science $357(6358): 1350-1352$

Van de Poel I (2000) On the role of outsiders in technical development. Technol Anal Strat Manag 12:383-397

Van de Ven AH, Polley DE, Garud R, Ventkatarman S (1999) The Innovation Journey. Oxford University Press, New York

Waluszewski A, Baraldi C, Ciabuschi F (2018) Increase development and decrease use! Innovation controversies caused by antimicrobial resistance. In: Thomas $\mathrm{H}$, Antonella L, Margunn A (eds) Controversies in Healthcare Innovation Service, Technology and Organization. Palgrave Macmillan, Basinstoke, pp. 309-340

Wise R (2007) An overview of the Specialist Advisory Committee on Antimicrobial Resistance (SACAR) (2007). J Antimicrob Chemother 60(1):i5-i7

Zhou F, Yu T, Du R, Fan G, Liu Y, Liu Z, Xiang J, Wang Y, Song B, Gu X, Guan L, Wei Y, Li H, Wu X, Xu J, Tu S, Zhang Y, Chen H, Cao B (2020) Clinical course and risk factors for mortality of adult inpatients with COVID-19 in Wuhan, China: a retrospective cohort study. Lancet 395(10229):1054-1062

\section{Funding}

Open access funding provided by Uppsala University.

\section{Competing interests}

The authors declare no competing interests.

\section{Additional information}

Correspondence and requests for materials should be addressed to A.W.

Reprints and permission information is available at http://www.nature.com/reprints

Publisher's note Springer Nature remains neutral with regard to jurisdictional claims in published maps and institutional affiliations.

(c) (i) Open Access This article is licensed under a Creative Commons Attribution 4.0 International License, which permits use, sharing adaptation, distribution and reproduction in any medium or format, as long as you give appropriate credit to the original author(s) and the source, provide a link to the Creative Commons license, and indicate if changes were made. The images or other third party material in this article are included in the article's Creative Commons license, unless indicated otherwise in a credit line to the material. If material is not included in the article's Creative Commons license and your intended use is not permitted by statutory regulation or exceeds the permitted use, you will need to obtain permission directly from the copyright holder. To view a copy of this license, visit http://creativecommons.org/ licenses/by/4.0/.

(C) The Author(s) 2021 